\title{
Examining Construct Validity and Reliability of the Aggressiveness Scale
}

\author{
Nur Sahria Ali, Fatwa Tentama, Fadiah Andini Adjam
}

\begin{abstract}
The purpose of this study is to test the validity and reliability of aggressiveness construct and test the forms and indicators that form this variable. Aggressiveness is measured by two forms, namely hate or anger and instrumental aggression. The population in this study are all teenagers in the city of Yogyakarta. The sample in this study are 60 teenagers in the city of Yogyakarta. The sampling technique is accidental sampling. The data collection method used is aggressiveness scale. Research data were analyzed with Structural Equation Modeling (SEM) through the SmartPLS 3.2.8 program. Based on the results of data analysis, the forms and indicators that make up the aggressiveness variable are declared valid and reliable. The most dominant form that reflects the aggressiveness variable is instrumental aggression with a loading factor of 0.934. The weakest form which reflects the aggressiveness variable is hate or anger with a loading factor of 0.851. This shows that all forms and indicators are able to reflect and form variable aggressivens. Thus the measurement model can be accepted because the theory that describes the variable fit with empirical data obtained from the subject.
\end{abstract}

Keywords: Aggressiveness, Hate, Instrumental Aggression, Reliabilitas Konstruk, Validitas Konstruk, Partial Least Square.

\section{INTRODUCTION}

$\mathbf{S}_{\text {chools are educational institutions that can ideally }}$ produce human resources who have intellectual or emotional intelligence. But these goals have not been fully realized, this can be seen from the absence of synchronization between intellectual and emotional intelligence in students. Students already know the various norms that must be applied in relationships, but have not been able to apply them in the form of behavior. One effect of this intellectual and emotional intelligence imbalance is that there are still many aggressive behaviors displayed by students. Forms of aggressive behavior that is often shown by students include beating, kicking, cursing, insulting, threatening, teasing, damaging public facilities, fighting, and so on.

Aggressive behavior is generally more common in male students [1]. Aggressive behavior can be caused by various factors, including alcohol abuse [2], film exposure containing aggressive scene [3], peers aggressive behavior influence [4],

Revised Manuscript Received on February 05, 2020.

Nur Sahria Ali*, Master of Psychology, Ahmad Dahlan University, Yogyakarta, Indonesia. Email: nursahriaaliuad1708@gmail.com

Fatwa Tentama*, Master of Psychology, Ahmad Dahlan University, Yogyakarta, Indonesia. Email: fatwa.tentama@psy.uad.ac.id

Fadiah Andini Adjam, Master of Psychology, Ahmad Dahlan University, Yogyakarta, Indonesia. Email: dhiadachii@gmail.com

(C) The Authors. Published by Blue Eyes Intelligence Engineering and Sciences Publication (BEIESP). This is an open access article under the CC BY-NC-ND license (http://creativecommons.org/licenses/by-nc-nd/4.0/)
* Correspondence Author

and teachers who often show aggressive behavior [5].

Adolescents who are accustomed to aggressive behavior tend to experience decreased sleep quality and low coping abilities [6]. Aggressive behavior can lead to loosening of individual relationships with peers [7], leading to conflict [8], [9], [10], decreasing academic achievement [11], develop impulsive attitudes and reduce the ability to empathize [12].

Based on interviews with a number of teenagers in Yogyakarta, it was revealed that when they were joking there was often misunderstanding between friends so they quieted down, greeted friends harshly, took friends' items they liked without their permission, smoked, and did not accept criticism from others. This phenomenon is found evenly in adolescents, so that such a situation is very worrying for the surrounding environment and the family.

In the psychological approach there is an approach from an umbrella theory that underlies thinking about aggression. One of them is the instinct theory put forward by Sigmund Frued. Freud [13] explains that aggressive behavior is a reaction to various levels of conflict of interest. Aggressive behavior can occur at all levels of society, especially adolescents who are included in very vulnerable groups. Adolescence is a time when individuals show behavior or behavioral tendencies that are to hurt others, both physically and psychologically to express negative feelings so they can achieve the desired goals [14]. Besides aggressive behavior aims to damage, injure or afflict a certain object or party. Aggression is important both in the world of individuals, relationships between individuals and in society [15]

Aggressive behavior is intentional physical and verbal behavior that aims to hurt and harm others [16]. Then according to Baron and Byrne [17] aggressive behavior is deliberate torture to hurt others who are driven by anger and the desire to vent their anger or to achieve other goals. Buss and Perry [14] revealed aggressive behavior as a behavior that is done to hurt, threaten, to endanger others both physically and verbally and both directly and indirectly.

Based on the above understanding put forward by some of the figures, it can be concluded that aggressive behavior is behavior that is done to hurt others as an outlet for anger or to achieve the goals by hurting physically, verbally, or passively so as to produce certain effects both physically and psychologically.Myers [18] suggests two forms of aggressive behavior, namely: 1) Aggression of hatred or anger which is a form of aggression carried out as a means to achieve other goals marked by high emotions resulting in inability to think about what happened and cause harm.

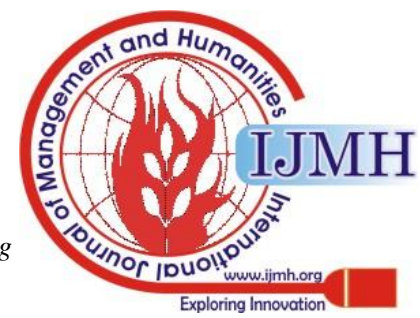


The other type of aggression is instrumental aggression which is aggression carried out not accompanied by emotions but committed by people who previously had no relationship between each other, such as the behavior of stealing, robbing, snatching up to rape.

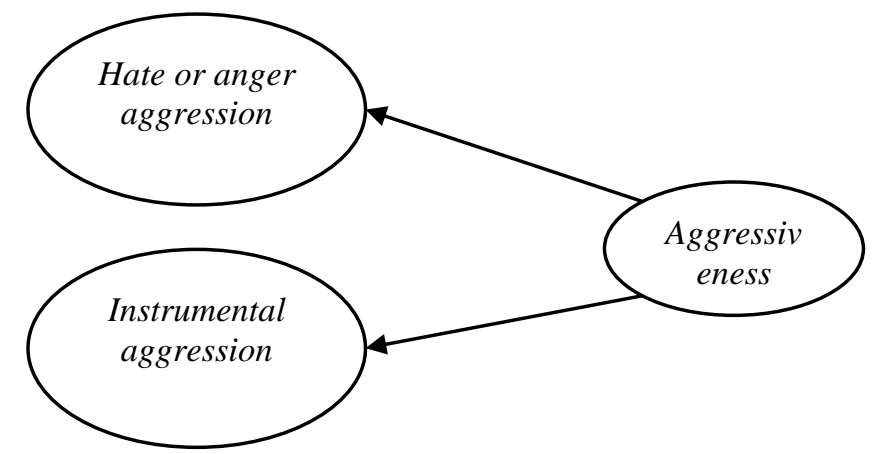

Figure 1. Conceptual model of aggressiveness

Based on Figure 1 above, the hypotheses proposed in this study are: 1) Aggressiveness scale measurement model that is fit with empirical data is formed. 2) Hate or anger aggression and instrumental aggression are able to form aggressiveness variables.

One approach that can be used in testing the construct of a measuring instrument is Confirmatory Factor Analysis (CFA). It is one of the main approaches in factor analysis. Confirmatory Factor Analysis (CFA) can be used to test the forms of a construct. This test is used to measure the model (model measurement) so that it can describe the forms in reflecting latent variables namely aggressiveness by looking at the loading factor of each form of a construct. Confirmatory Factor Analysis (CFA) is also used to test the construct validity and construct reliability of the indicators (items) forming latent variables [19]. Confirmatory Factor Analysis (CFA) used in this study is the second order Confirmatory Factor Analysis (2nd Order CFA), a measurement model that consists of two levels. The first level of analysis is carried out from the forms to the indicators and the second analysis is carried out from the latent variable to the forms [19].

Based on the description above, the formulation of the problem in this study are: 1) Is the scale of aggressiveness valid and reliable? The purpose of this research is to test the validity and reliability of the construct on the scale of aggressiveness, and test the forms and indicators that can form the variable aggressiveness.

\section{METHOD}

\section{A. Population and Sample}

The population in this study are all teenagers in the city of Yogyakarta and the sample consists of 60 teenagers. The sampling technique used in this study is accidental sampling.

\section{B. Data Collection Method}

Aggressiveness in this study was measured using an aggressiveness scale with a Likert scaling model. The scale of this study was arranged by the researcher by referring to the forms of aggressiveness according to Myers [18], namely hate or anger aggression and instrumental aggression. Examples of items that are in the form of hate or anger aggression are "I rarely give advice, when friends are having difficulties" and "When friends invite brawls, I refuse". Then examples of items in the form of instrumental aggression are "When I like other people's belongings, I take it" and "When I am criticized, I choose to be quiet". Blueprint as a reference in developing aggressiveness scale can be seen in table 1.

Table 1. The blueprint of aggresiveness

\begin{tabular}{|c|c|c|c|c|}
\hline \multirow{2}{*}{\begin{tabular}{|l} 
Form of \\
Aggressivenes
\end{tabular}} & \multirow[t]{2}{*}{ Indicator } & \multicolumn{2}{|c|}{ Item number } & \multirow[t]{2}{*}{ Total } \\
\hline & & Favorable & Unfavorable & \\
\hline \multirow[t]{2}{*}{ Anger } & \begin{tabular}{|l} 
a. Committing \\
physical \\
harm
\end{tabular} & $1,9,17$ & $5,13,21$ & \multirow[t]{2}{*}{12} \\
\hline & b. Cursing & $2,10,18$ & $6,14,22$ & \\
\hline \multirow{2}{*}{$\begin{array}{l}\text { Instrumental } \\
\text { Aggression }\end{array}$} & a. Stealing & $3,11,19$ & $7,15,23$ & \multirow[t]{2}{*}{12} \\
\hline & b. Attacking & $4,12,20$ & $8,16,24$ & \\
\hline \multicolumn{4}{|c|}{ Total } & 24 \\
\hline
\end{tabular}

\section{Construct Validity and Reliability}

To test the construct validity and construct reliability, this study uses the outer model testing through the smartPLS 3.2.8 program. The construct validity test was conducted to show the ability of each item or indicator (observed variable) to reflect each aspect and to reflect the variable (laten variable).

The construct validity test consists of convergent and discriminant validity tests. Convergent validity can be seen from the loading factor and the Average Variance Extracted (AVE) value of $>0.5$ [20]. According to Hair, Black, Babin, and Anderson [21] the higher the factor loading score, the more important the role of loading will be in interpreting the factor matrix. A loading factor and AVE value of $>0.5$ are considered significant [20]. While discriminant validity can be seen from comparing the roots value of the Average Variance Extracted (AVE) between aspects in which it must be higher than the correlation with other aspects [20].

\section{Construct Reliability}

The construct reliability test was conducted to find out the internal consistency of the measuring instrument by looking at the value of composite reliability and Cronbach alpha. It would show the consistency value of each item in measuring latent variables. A higher value would show the consistency of value of each item in measuring latent variables. According to Hair, Black, Babin, and Anderson [21] the expected composite reliability and Cronbach alpha values are $>0.7$ and 0.6 values are still acceptable [20].

\section{E. Data Analysis}

The data in this study were analyzed using the outer model with the 2nd order CFA approach through the SmartPLS 3.2.8 program. According to Abdillah and Hartono [22] Partial Least Square (PLS) is a variant-based Structural Equation Model (SEM) that can simultaneously test measurement models to test the construct validity and reliability.

\section{RESULT}

The result of outer model aggressiveness scale testing that has been done using the smart PLS 3.2.8 program can be seen in figure 2 below.

Published By:

Blue Eyes Intelligence Engineering

\& Sciences Publication

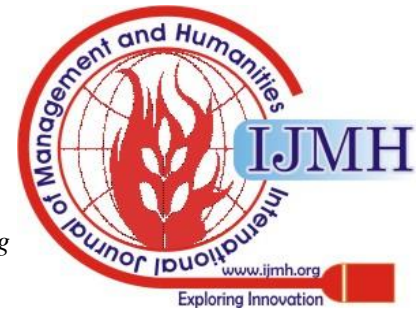




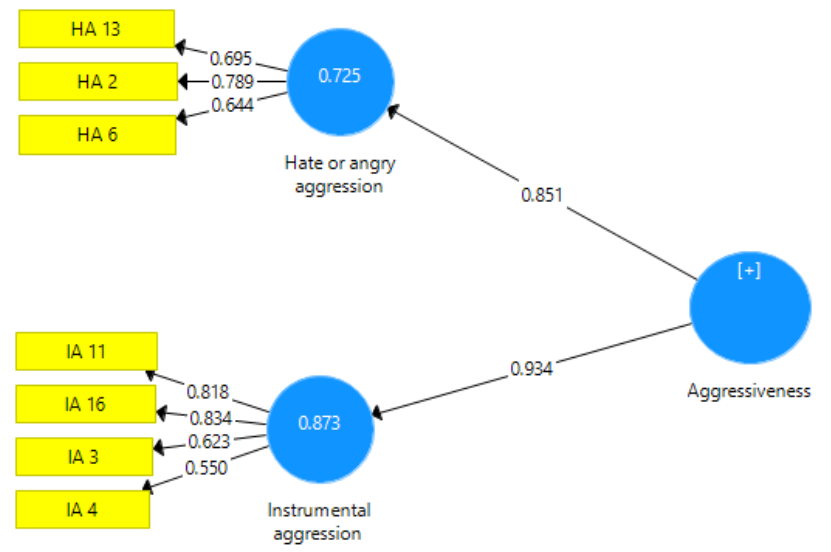

Figure 2. Output outer model of aggressiveness scale

\section{A. Construct Validity Test Result}

1. Convergent Validity

Convergent validity test results are performed by testing the outer model seen from the loading factor value and Average Variance Extacted (AVE). Based on the data analysis, it was found that the loading factor value from variables to forms and from forms to indicators is $>0.5$. Loading factor weights of 0.5 or more are considered to have validation that is strong enough to explain latent constructs [21]. The results of convergent validity testing can be seen in table 2 and table 3.

Table 2. Loading factor value (variable-aspect)

\begin{tabular}{|l|c|c|}
\hline \multicolumn{1}{|c|}{ Types } & Loading Factor & Explanation \\
\hline $\begin{array}{l}\text { Hate or angry } \\
\text { aggression }\end{array}$ & 0.851 & Valid \\
\hline $\begin{array}{l}\text { Instrumental } \\
\text { aggression }\end{array}$ & 0.934 & Valid \\
\hline
\end{tabular}

Table 3. Loading factor value (aspect-item)

\begin{tabular}{|c|c|c|}
\hline Item & Loading Factor & Explanation \\
\hline HA 13 & 0.695 & Valid \\
\hline HA 2 & 0.789 & Valid \\
\hline HA 6 & 0.644 & Valid \\
\hline IA 4 & 0.818 & Valid \\
\hline IA 3 & 0.834 & Valid \\
\hline IA 11 & 0.623 & Valid \\
\hline IA 16 & 0.550 & Valid \\
\hline
\end{tabular}

Furthermore, the results of the convergent validity test show the Average Variance Extacted (AVE) value of $>0.5$. The Average Variance Extacted (AVE) value of the aggressiveness variable is 0.505 and the Average Variance Extacted (AVE) value of each form can be seen in table 4 .

Table 4. Average variance extracted (AVE) value

\begin{tabular}{|l|c|c|}
\hline \multicolumn{1}{|c|}{ Types } & AVE & Explanation \\
\hline $\begin{array}{l}\text { Hate or angry } \\
\text { aggression }\end{array}$ & 0.507 & Valid \\
\hline $\begin{array}{l}\text { Instrumental } \\
\text { aggression }\end{array}$ & 0.514 & Valid \\
\hline
\end{tabular}

\section{Discriminant Validity}

The results of the discriminant validity test showed that the root value of the Average Variance Extacted (AVE) in each form is higher than the root value of the Average Variance Extacted (AVE) in other forms, so that the discriminant validity criteria are met. The root value of the Average Variance Extacted (AVE) aggressiveness variable can be seen in table 5.
Table 5. AVE root value of servant leadership

\begin{tabular}{|l|c|c|}
\hline \multicolumn{1}{|c|}{ Type } & $\begin{array}{c}\text { Hate or anger } \\
\text { aggression }\end{array}$ & $\begin{array}{c}\text { Instrumental } \\
\text { aggression }\end{array}$ \\
\hline Hate or angry aggression & 0.712 & 0.670 \\
\hline Instrumental aggression & 0.670 & 0.717 \\
\hline
\end{tabular}

\section{B. Construct Reliability Test Result}

Construct reliability testing is done by testing the outer model which is seen from the value of composite reliability and Cronbach alpha. This test is done by looking at the value of composite reliability and Cronbach alpha of $>0.7$ which means that the scale in this study is reliable. The composite reliability and Cronbach alpha values can be seen in table 6 .

Table 6. Composite reliability and Cronbach alpha value of aggressiveness

\begin{tabular}{|c|c|c|c|}
\hline Variable & $\begin{array}{c}\text { Composite } \\
\text { Reliability }\end{array}$ & Cronbach Alpha & Explanation \\
\hline Agressiveness & 0.835 & 0.751 & Reliable \\
\hline
\end{tabular}

The results of the construct reliability test in table 6 shows that the aggressiveness scale has good reliability and it means that the form that measures the latent aggressiveness variable meets the unidimensional criteria [21]. This is indicated by the composite reliability value of 0.835 and Cronbach alpha of 0.751 . The construct validity and reliability tests produce valid and reliable items that are able to reflect the forms of aggressiveness, those are items in numbers 2,3,4,6,11,13 and 16. Whereas the items that are not able to reflect aggressiveness are the items numbers $1,5,7,8,9,10,12,14,15,17,18,19,20,21,22,23$ and 24 . The analysis of research data using the outer model testing shows that the measurement model can be accepted, because all forms are able to reflect the variables formed.

\section{DISCUSSION}

Based on the results of the analysis of construct validity and construct reliability, the forms and indicators that make up the aggressiveness variable are declared valid and reliable. It shows that all existing forms and indicators are able to reflect and shape the aggressiveness variable. The most dominant aspect that is able to reflect aggressiveness is instrumental aggression with a loading factor value of 0.934 , reflecting form of behavior such as stealing and attacking. However, valid and reliable indicators show that when friends invite for brawls, the student refuses. In addition students also scold when there are friends who are talking about other friends. But when there are friends who have difficulties, they rarely give advice. Relevant research results show that individuals with high instrumental aggression tend to be reactive [23], difficult to control [24], manipulative and irresponsible [25].

The weakest form of aggressiveness which reflects aggressiveness is hate or anger aggression with a loading factor value of 0.851 . It involves the form of behavior such as physical violence and verbal abuse. Valid and reliable indicators show that students take their friends' belongings secretly and students insinuate new people. Different from other forms of aggression, this form of aggression has more specific goals [26].

Published By:

Blue Eyes Intelligence Engineering

\& Sciences Publication

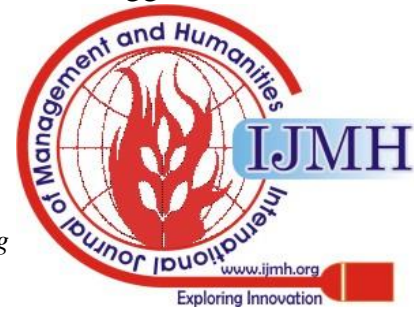


The findings of this study are supported by the theory or concept described by Albouza and Chazaud [27], Vander Meij, Almela, Buunk, Dubbs and Salvador [28] which state that aggression in adolescents is dominated by aggression of hatred or anger towards peers. In addition, this finding is also supported by the results of an empirical study conducted by Archer and Thanzami [29] which states that aggression in adolescents tends to be reactive (hostile), forms of behavior such as reacting angrily when provoked by others, and becoming angry when frustrated. While proactive (instrumental) aggression, the behavior is in the form of fighting with others to show who is more superior, and injuring others to win the game.

The results of previous studies concerning the variables of aggressiveness relevant to this study which also explained the validity and reliability of this variable is the research of De Boo, and Kolk [30] which proves that the scale of aggressiveness meets the reliability requirements with a Cronbach alpha value of 0.70 . Other research results that also explain the validity and reliability are Nesbit, Blankenship, and Murray [31] proving that the scale of aggressiveness meets the reliability requirements with a Cronbach alpha value of 0.680 . Furthermore, the aggressiveness scale also fulfills the reliability requirements with Cronbach alpha 0.70 [32], Cronbach alpha 0.750 [33] and Cronbach aplha 0.71 [34]. The above results, when compared with the results of this study shows that the aggressiveness scale in this study is also appropriate to be used or applied in expressing aggressiveness in students, because the analysis results show that this aggressiveness scale has better and reliable validity and reliability with a composite reliability of 0.835 and Cronbach alpha of 0.751 .

The results of this study are expected to provide an overview of the validity and reliability of the aggressiveness scale in the context of adolescents in Yogyakarta so that it can be used in research data collection and become a reference in further research related to aggressiveness.

\section{CONCLUSSION}

Based on the results of the analysis and discussion it can beholme concluded that: 1) Aggressiveness scale meets the validity and reliability. The validity of aggressiveness scale reflected from the value of loading factor, average variance extracted (AVE) and the AVE root value from the forms, whereupon the reliability of aggressiveness scale reflected from the value of composite reliability and Cronbach alpha.2) All forms and indicators can form aggressiveness variables, namely hate or anger aggression and instrumental aggression. It reflecterd from the loading factor value of every form of agressiveness.The most dominant aspect describing aggressiveness is instrumental aggression and the weakest aspect describing aggressiveness is hate or anger aggression. In this study an aggressiveness scale measurement model is formed that is in accordance with empirical data obtained from subjects at the study site.

\section{ACKNOWLEDGMENT}

The author would like to thank Ahmad Dahlan University and the Master of Psychology Programme University of Ahmad Dahlan for supporting the implementation of this research.

\section{REFERENCES}

1. K. Mouratidou, S. Karamavrou, S. Karatza, and Schillinger, M. (2019) Aggressive and socially insecure behaviors in kindergarten and elementary school students: a comparative study concerning gender, age and geographical background of children in Northern Greece. Social Psychology of Education, 1-19. https://link.springer.com/article/10.1007/s11218-019-09536-z

2. K. Ritter, S.J. Lookatch, M.R. Schmidt, and T.M. Moore. (2019). The impact of history of aggression and alcohol use on aggressive: responding in the laboratory. Substance Abuse: Research and Treatment,Vol.13.https://journals.sagepub.com/doi/abs/10.1177/1178 221819884328

3. S.M. Coyne, J.R. Linder, E.E. Rasmussen, D.A. Nelson, and V. Birkbeck. (2016). Pretty as a princess: Longitudinal effects of engagement with Disney princesses on gender stereotypes, body esteem, and prosocial behavior in children. Child development, Vol. 87, No. 6, pp.1909-1925. 3 . https://onlinelibrary.wiley.com/doi/abs/10.1111/cdev.12569

4. K.M. Fikkers, J.T. Piotrowski, P. Lugtig, and P.M. Valkenburg. (2016). The role of perceived peer norms in the relationship between media violence exposure and adolescents' aggression. Media $\begin{array}{lllll}\text { Psychology, } & \text { Vol. } & 19, & \text { No.1, } & \text { pp. }\end{array}$ https://www.tandfonline.com/doi/abs/10.1080/15213269.2015.103796 0

5. I. Syrmpas, and A. Bekiari. (2018). Differences between leadership style and verbal aggressiveness profile of coaches and the satisfaction and goal orientation of young athletes. Journal of Physical Education and Sport, Vol. 18, pp. 1008-1015 https://efsupit.ro/images/stories/iulie2018/Art\%20149.pdf

6. C.E. Brown, C.M. Borduin, A.R. Dopp, and M.O. Mazurek. (2019). The social ecology of aggression in youths with autism spectrum disorder. Autism Research. https://onlinelibrary.wiley.com/doi/abs/10.1002/aur.2157.

7. M. Sollitto, and G.A. Cranmer. (2019). The Relationship Between Aggressive Communication Traits and Organizational Assimilation. International Journal of Business Communication, Vol. 56, No. 2, pp. 278-296.https://journals.sagepub.com/doi/abs/10.1177/232948841561 3339

8. L.S. Aloia. (2018). Verbal Aggression in Romantic Relationships: The Influence of Family History, Destructive Beliefs About Conflict, and Conflict Goals. Communication Quarterly, Vol. 66, No. 3, pp. 308-324.

https://www.tandfonline.com/doi/abs/10.1080/01463373.2017.138162 6

9. S. Deliligka, and A. Bekiari. (2018). Multi-Parametric Analysis of Aggressive Communication and Motivation Climate in Physical Education. Psychology, Vol.9, $\quad$ No. 2. https://www.scirp.org/html/2-6902335_82440.htm

10. N.C. Andrews, L.D. Hanish, K.A. Updegraff, D. DeLay, and C.L Martin. (2019). Dyadic peer interactions: the impact of aggression on impression formation with new peers. Journal of Abnormal Child Psychology, Vol. 47, No. 5, pp. 839-850. https://link.springer.com/article/10.1007/s10802-018-0490-y

11. O. Uludag. (2013). The influence of aggression on students' achievement: Evidence from higher education. Procedia-Social and Behavioral Sciences, Vol. 89, pp. 954-958. https://www.sciencedirect.com/science/article/pii/S187704281303094 2.

12. T. Velki. (2018). Verifying the ecological model of peer aggression on Croatian students. Psychology in the Schools, Vol. 55, No. 10, pp 1302-1320. https://onlinelibrary.wiley.com/doi/abs/10.1002/pits.22178

13. S. Freud. (1964). Analysis terminable and interminable. In The Standard Edition of the Complete Psychological Works of Sigmund Freud, Volume XXIII (1937-1939): Moses and Monotheism, An Outline of Psycho-Analysis and Other Works, pp. 209-254 https://psycnet.apa.org/record/1964-35016-000

14. A.H. Buss, and M. Perry. (1992). The aggression questionnaire. Journal of Personality and Social Psychology, Vol. 63, No.3, pp. 452. https://psycnet.apa.org/buy/1993-00039-001

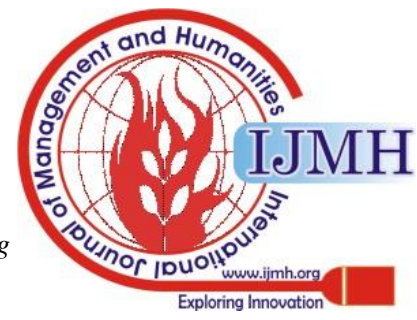


15. C.N. DeWall, C. N., Finkel, T.F. Denson. (2011). Self-control inhibits aggression. Social and Personality Psychology Compass, Vol. 5, No.7, pp. $458-472$. https://onlinelibrary.wiley.com/doi/abs/10.1111/j.1751-9004.2011.00 363.x

16. N.N. Singh, G.E. Lancioni, B.T. Karazsia, A.S. Winton, R.E. Myers, A.N. Singh, and J. Singh. (2013). Mindfulness-based treatment of aggression in individuals with mild intellectual disabilities: A waiting list control study. Mindfulness, Vol. 4, No. 2, pp. 158-167. https://link.springer.com/article/10.1007/s12671-012-0180-8

17. Baron, A. Robert, and D. Byrne. (2005). Social psychology (in Indonesia). Jakarta: Erlangga.

18. D.G. Myers. (2012). Social psychology (in Indonesia). Jakarta: Salemba Humanika.

19. H. Latan, Structural equation modeling concepts and applications using LISREL 8.80 (In Indonesia). Bandung: Alfabeta, 2012.

20. H.M. Jogiyanto, Concept and application of structural equation modeling based on variants in business research (In Indonesia).Yogyakarta.: UPP STIM YKPN, 2011.

21. J.F. Hair, W.C. Black, B.J. Babin and R.E. Anderson, Multivariate data analysis. Upper Saddle River: Prentice Hall, 2010.

22. W. Abdillah, and J. Hartono, Partial least square (PLS): Alternatif structural equation modeling (SEM) dalam penelitian bisnis. Yogyakarta: Andi, 2015.

23. A.L. Glenn, and A. Raine. (2009). Psychopathy and instrumental aggression: Evolutionary, neurobiological, and legal perspectives. International journal of law and psychiatry, Vol. 32, No. 4, pp. 253-258.

https://www.sciencedirect.com/science/article/pii/S016025270900045 4

24. R.G. Fontaine. (2007). Disentangling the psychology and law of instrumental and reactive subtypes of aggression. Psychology, Public Policy, and Law, Vol. 13, No. 2, https://psycnet.apa.org/doiLanding?doi=10.1037/1076-8971.13.2.143

25. M. J. Vitacco, C.S. Neumann, M.F. Caldwell, A.M. Leistico, and Van G.J. Rybroek. (2006). Testing factor models of the Psychopathy Checklist: Youth Version and their association with instrumental aggression. Journal of personality assessment, Vol. 87, No. 1, pp. 74-83.

https://www.tandfonline.com/doi/abs/10.1207/s15327752jpa8701_06

26. K.M. Craig. (2002). Examining hate-motivated aggression: A review of the social psychological literature on hate crimes as a distinct form of aggression. Aggression and Violent Behavior, Vol. 7, No. 1, pp. 85-101.

https://www.sciencedirect.com/science/article/pii/S135917890000039 2

27. Y. Albouza, and P. Chazaud. (2019). French Validation of the Competitive Aggressiveness and Anger Scale (FVCAAS). Psychologie Française, Vol. 64, No. 4, pp. 315-330. https://www.sciencedirect.com/science/article/pii/S003329841830066 9

28. L. VanderMeij, M. Almela, A.P. Buunk, S. Dubbs, and A. Salvador. (2012). 2 D: 4 D in Men Is Related to Aggressive Dominance but Not to Sociable Dominance. Aggressive Behavior, Vol. 38, No. 3, pp. 208-212. https://onlinelibrary.wiley.com/doi/abs/10.1002/ab.21422

29. J. Archer, and V. Thanzami. (2009). The relation between mate value, entitlement, physical aggression, size and strength among a sample of young Indian men. Evolution and Human Behavior, Vol. 30, No. 5, pp. 315-321.https://www.sciencedirect.com/science/article/pii/S10905138 09000257

30. G.M. De Boo, and A.M. Kolk. (2007). Ethnic and gender differences in temperament, and the relationship between temperament and Depressive and Aggressive mood. Personality and Individual Differences, Vol. 43, No. https://www.sciencedirect.com/science/article/pii/S019188690700182 1

31. S.M. Nesbit, K.L. Blankenship, and R.A. Murray, R. A. (2012). The Influence of Just-World Beliefs on Driving Anger and Aggressive Driving Intentions. Aggressive Behavior, Vol. 38, No. 5, pp. 389-402. https://onlinelibrary.wiley.com/doi/abs/10.1002/ab.21439

32. S. Côté, R. Tremblay, and F. Vitaro. (2003). Le développement de l'agression physique au cours de l'enfance: différences entre les sexes et facteurs de risque familiaux. Sociologie et Sociétés, Vol. 35, No. 1, pp.

$203-220$ https://www.erudit.org/en/journals/socsoc/1900-v1-n1-socsoc702/008 517ar/abstract

33. J.L. Alcorn III, J.L. Gowin, C.E. Green, A.C. Swann, F.G. Moeller, and S.D. Lane. (2013). Aggression, impulsivity, and psychopathic traits in combined antisocial personality disorder and substance use disorder. The Journal of Neuropsychiatry and Clinical Neurosciences,
Vol. 25, No. $\quad 3, \quad$ pp. 229-232. https://neuro.psychiatryonline.org/doi/abs/10.1176/appi.neuropsych.1 203006

34. J. Hosie, F. Gilbert, K. Simpson, and M. Daffern. (2013). An examination of the relationship between personality and aggression using the general aggression and five factor models. Aggressive Behavior, Vol. 40, No. 2, pp. 189-196. 30 https://onlinelibrary.wiley.com/doi/abs/10.1002/ab.21510

\section{AUTHORS PROFILE}

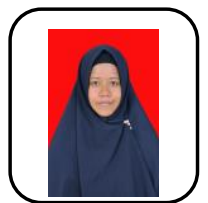

Nur Sahria Ali, was born November 10, 1994 in Ambon. She is a student at Master of Psychology, Universitas Ahmad Dahlan Yogyakarta. Her scientific focus is educational psychology.

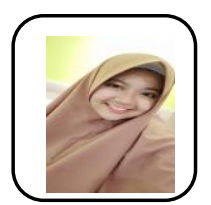

Fatwa Tentama, was born on October 1, 1984 in Yogyakarta. Working as a lecturer at the Faculty of Psychology at Ahmad Dahlan University, Yogyakarta. His scientific focus and research is industrial psychology and educational psychology.

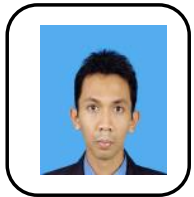

Fadiah Andini Adjam, Was born July 27, 1994 in Manado. She is a student at Master of Psychology, Universitas Ahmad Dahlan Yogyakarta. Her scientific focus is educational psychology.

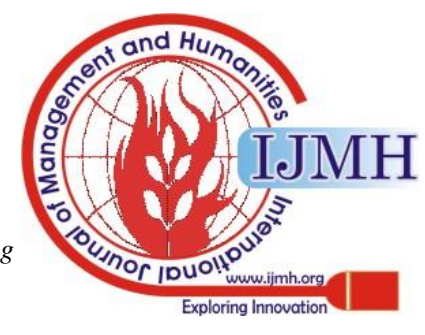

